\title{
Interactive comment on "Temporal variability of social vulnerability to storm surges in Shenzhen, China” by Huaming Yu et al.
}

Huaming Yu et al.

hmyu@ouc.edu.cn

Received and published: 13 February 2020

The research group thanks Anonymous Reviewer \#2 for their careful review, constructive feedback and technical screening. We know the reviewer's comments, suggestions and list of technical corrections will allow our group to forge an enhanced version of the manuscript. Please see the supplemental PDF for our responses to all specific comments and technical corrections.

Please also note the supplement to this comment:

Printer-friendly version https://www.nat-hazards-earth-syst-sci-discuss.net/nhess-2019-293/nhess-2019-293AC2-supplement.pdf 
Interactive comment on Nat. Hazards Earth Syst. Sci. Discuss., https://doi.org/10.5194/nhess2019-293, 2019.

\section{NHESSD}

Interactive

comment 